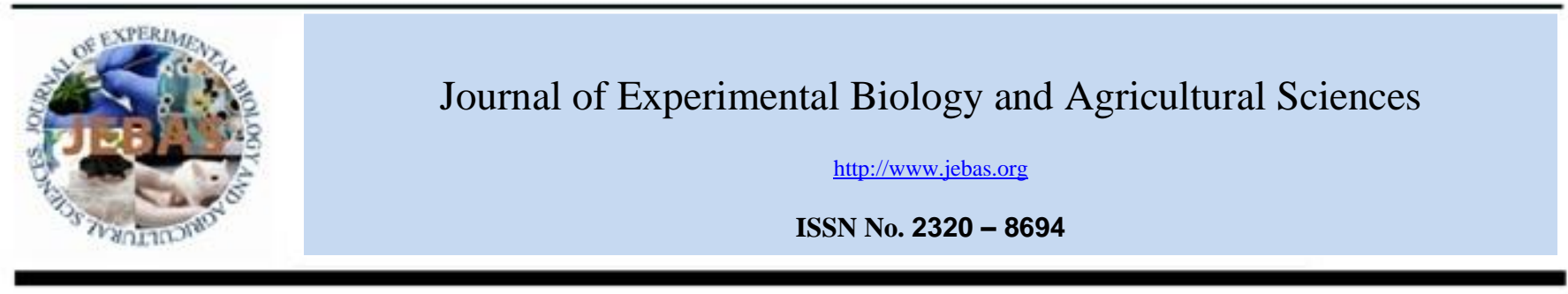

\title{
EFFECT OF PAPAYA AND STORAGE TIME ON THE QUALITY OF THE NEWLY DEVELOPED PAPAYA CRACKERS
}

\author{
Habiba Khatun ${ }^{1, *}$, Nusrat $\operatorname{Jahan}^{1}$, Mojaffor Hosain ${ }^{2}$, Trisna Mardy ${ }^{1}$ and Shahinur Rahman ${ }^{1}$ \\ ${ }^{1}$ Departmentof Food Science and Nutrition, Hajee Mohammad Danesh Science and Technology University, Dinajpur-5200 \\ ${ }^{2}$ Departmentof Food Processing and Preservation, Hajee Mohammad Danesh Science and Technology University, Dinajpur-5200 \\ Received - March 03, 2016; Revision - March 17, 2016; Accepted - April 20, 2016 \\ Available Online - April 25, 2016
}

DOI: http://dx.doi.org/10.18006/2016.4(2).194.200

\begin{abstract}
KEYWORDS
Crackers

Physicochemical

characteristics

Papaya

Whole wheat flour

Storage time

ABSTRACT

Crispy nutritious papaya crackers were developed from locally available papaya and whole wheat flour by baking in oven at $130^{\circ} \mathrm{C}$ for $35 \mathrm{~min}$. Crackers were packed in high density polyethylene pouches and stored under ambient condition for 90 days. The influence of papaya and storage condition on physicochemical compositions was evaluated in present study. Physicochemical analyses of fresh crackers revealed the presence of moisture (3.3-3.6\%), ash (4.07-4.12\%), protein $(6.35-8.13 \%)$, fat (1.75-1.94\%), fibers (11.50-13.75\%), minerals like sodium (6.1-6.61 mg/100g), magnesium (122.44$115.28 \mathrm{mg} / 100 \mathrm{~g})$, potassium $(469.62-443.34 \mathrm{mg} / 100 \mathrm{~g})$, calcium $(24.99-21.97 \mathrm{mg} / 100 \mathrm{~g})$ and phosphorus (307.66-229.13 mg/100g). Among various studied physicochemical parameters only slight increases was reported in the moisture content while in case of other parameters like fat, ash, fiber, protein and mineral content some reduction was reported at the 90 days of storage. This study introduced the formulation of crackers by using whole wheat flour and papaya which can be a good source of fiber and minerals.
\end{abstract}

* Corresponding author

E-mail: habiba5418@gmail.com (Habiba Khatun)

Peer review under responsibility of Journal of Experimental Biology and Agricultural Sciences.

Production and Hosting by Horizon Publisher India [HPI] (http://www.horizonpublisherindia.in/).

All rights reserved.
All the article published by Journal of Experimental Biology and Agricultural Sciences is licensed under a Creative Commons Attribution-NonCommercial 4.0 International License Based on a work at www.jebas.org.

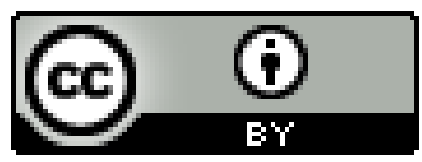




\section{Introduction}

Papaya (Carica papaya L.) is one of the important and versatile fruits of the family Caricaceae and grown worldwide in the tropics and subtropics including India, Bangladesh, Malaysia, Australia, Hawaii, Philippines, Sri Lanka, South Africa and other countries in tropical America (Anuara, 2008). In Bangladesh, papaya is available all around the year, therefore ripe papaya is consumed as fruit and green papaya as vegetable. According to BBS (2011), papaya production in Bangladesh was 1.25 lac metric tons from 1.24 thousand hectares of land with an average yield of 7 ton/ha. However, it was also reported that papaya production in Bangladesh is far below compared to other neighboring countries (Chowdhury, 2008). Furthermore, post-harvest losses of papaya is recorded almost 39.9\% in Bangladesh (Hasan, 2010) and it is a major cause of unavailability of papaya (Mondal et al., 1995). Unavailability of effective preservation and processing techniques are major reasons of post-harvest losses of papaya.

Nowadays, fast food snacks especially crackers have emerged as popular items because of unique flavor and texture to the modern consumers of all age groups. Excess use of these fast foods can be harmful for human beings and according to Thunstrom (2011), higher consumption of these fast food items can cause several diseases like diabetes, cardiovascular disease, cancer, dental caries and osteoporosis, overweight as well as obesity because of less fiber and excess fat content.

On the other hand, dietary fiber is tremendous attention in food processing where bakery products could be modified by addition of value added ingredients (Vergara-Valencia et al., 2006; Sudha et al., 2007). Consumption of food made of whole grain is associated with the lowering of glucose level in blood, cardiovascular disease, cancers and other diseases because of its dietary fiber and micronutrients (McKeown et al., 2002). High amount of dietary fiber, vitamin E, vitamin B complex, minerals, antioxidants and phytoestrogens are found in the bran and germ of whole grains (Jacobs et al., 1998). In Bangladesh, there are less whole wheat products whereas in developed countries, whole wheat products have been gained much popularity.

Fresh papaya could be explored for the production of papaya crackers. It can be used incorporation with wheat flour for better quality crackers. According to Tietze (2002), mature papaya is a rich source of vitamin A, E, B complex, ascorbic acid compared to carrots and oranges. Furthermore, a recent study also shows that papaya contains arginine amino acid, which is essential for male fertility (Rovira, 2009).

Therefore, papaya crackers with whole grain flour may be one of potential processed products in Bangladesh. In some areas of Bangladesh, papaya is very cheap due to lack of storage, transportation and processing facility. Moreover, substantial amount of foreign exchange could be earned by processing and exporting papaya crackers. Based on the above discussion, the present work was aimed to formulate and analyze the nutritional composition of papaya crackers and also, to assess the storage stability of prepared papaya crackers.

\section{Materials and methods}

\subsection{Sample collection}

Fresh, fully mature and sound papaya and whole wheat flour were purchased from local market at Basherhat for preparation of crackers.

\subsection{Formulation of papaya crackers}

Three formulations of papaya crackers viz F1, F2 and F3 were developed using papaya and whole grain wheat flour with the addition of seasoning (baking powder, corn flour, sugar, garlic, ginger and salt) as given in Table 1.

Table 1 Different formulations of papaya crackers.

\begin{tabular}{|lccc|} 
Formulation & \multicolumn{2}{c|}{ Ingredient } \\
\hline & $\begin{array}{c}\text { Papaya } \\
(\%)\end{array}$ & $\begin{array}{c}\text { Whole } \\
\text { wheat }(\%)\end{array}$ & $\begin{array}{c}\text { Seasoning } \\
(\%)\end{array}$ \\
\hline F1 & 40 & 50 & 10 \\
\hline F2 & 30 & 60 & 10 \\
\hline F3 & 20 & 70 & 10 \\
\hline
\end{tabular}

2.3 Preparation of papaya crackers

Clean and disease free whole wheat was turned into flour by hammer mill. Simultaneously, papaya was washed with clean water and peeled and sliced longitudinally and boiled for $5 \mathrm{~min}$ at $180^{\circ} \mathrm{C}$. After boiling, papaya and whole wheat flour were taken in different combination in a bowl as described in Table 1. Boiled papaya was mashed and all seasoning ingredients (garlic, ginger) were added properly for making dough. Dough was transformed into sheet of $2 \mathrm{~mm}$ thick and cut into desirable shapes. After that, the cut pieces were baked at $130^{\circ} \mathrm{C}$ for $35 \mathrm{~min}$ in oven. After baking, crackers were cooled and packaged $(50 \mathrm{~g})$ in high density polyethylene pouches.

Fresh crackers were subjected to initial physicochemical analysis before packaging. The sealed packages were stored at ambient condition (temperature $25 \pm 2^{\circ} \mathrm{C}$ and relative humidity $68 \pm 3 \%$ ) for storage studies at 30 days intervals for 90 days.

\subsection{Physico-chemical analysis}

Physico-chemical analyses namely, moisture, ash, protein and fat content were carried out according to standard methods of AOAC (1997). The crude fiber was determined by the method of Ayesha et al. (2002) with slight modification. 
The available minerals (calcium, magnesium, potassium, phosphorous and sodium) were determined by atomic absorption methods described by Wahab et al. (2010) with some modifications. For this, one gram of the crackers sample was taken in $50 \mathrm{ml}$ flask. Then, $10 \mathrm{ml}$ of concentrated nitric acid and $5 \mathrm{ml}$ of concentrate edperchloric acid were added to the flask and digested using a hot plate until complete removal of white smoke and solution become clear. $20-30 \mathrm{ml}$ of distilled water was then added and filtered, and final volume was made up to $100 \mathrm{ml}$ with distilled water. Absorbance was measured by using atomic absorption spectrophotometer.

\subsection{Statistical Analysis}

All measurements were carried out in triplicate. The data were analyzed using statistical program SPSS (version 20.0) and significant differences were compared by analysis of variance test (ANOVA) following Duncan's Multiple Range Tests at the significance level of $5 \%$.

\section{Results and Discussion}

3.1 Physico-chemical characteristics of papaya and whole wheat flour

Data regarding physico-chemical characteristics of green papaya and whole wheat flour have been presented in Table 2 . It was observed that green papaya showed high moisture $(88.2 \%)$, ash $(0.63 \%)$, very low protein $(0.57 \%)$, fat $(0.63 \%)$ and crude fiber content $(0.75 \%)$. The results of present study are in agreement with the findings of Krishna et al. (2008). On the other hand, wheat flour showed moisture (12.5\%), ash (1.7\%), high protein $(12.3 \%)$, fat content $(1.8 \%)$ and fiber content (1.9\%). The results are comparable with the findings of Belderok et al. (2000) who observed slight higher protein and less fiber content ( $13 \%$ and $1.5 \%$ respectively) in whole wheat endosperm.

Table 2 Physico-chemical characteristics of green papaya and whole wheat flour.

\begin{tabular}{|lcc|}
\hline Composition & Green papaya & Whole wheat flour \\
\hline Moisture (\%) & $88.2 \pm 0.23$ & $12.5 \pm 0.19$ \\
\hline Ash (\%) & $0.63 \pm 0.08$ & $1.7 \pm 0.10$ \\
\hline Protein (\%) & $0.57 \pm 0.11$ & $12.3 \pm 0.34$ \\
\hline Fat (\%) & $0.63 \pm 0.14$ & $1.8 \pm 0.19$ \\
\hline Crude fiber (\%) & $0.75 \pm 0.12$ & $1.9 \pm 0.23$ \\
\hline
\end{tabular}

All values are means $\pm \mathrm{SD}$

3.2 Storage studies of papaya crackers

\subsubsection{Moisture content}

The moisture content of freshly prepared cracker samples F1, F2 and F3 was 3.3, 3.55 and 3.6\% respectively (Figure 1A).
It was observed that different ratio of papaya and whole grain flour significantly affected the moisture content of crackers. Figure 1A shows that moisture content of papaya crackers increased throughout the storage period. Change in moisture content was comparatively less for first 30 days of storage but later on the level of moisture content increased with the increasing duration of storage. Maximum increase (101.52\%) was reported in F1 sample, whereas minimum increase (72.22\%) was observed in F3 sample at the end of storage duration. The increase in moisture of crackers may be due to high water vapor transmission rate through packaging material. Finding of present study are in agreement with the findings of Jagdeesh et al. (2007) and Purohit \& Rajyalakshmi (2011). Furthermore, Manikantan et al. (2014) also observed an increase in moisture of banana chips stored in polypropylene based nanocomposite packaging films.

\subsubsection{Ash content}

Results of ash analysis were presented in Figure 1B. Ash content of fresh crackers of F1, F2 and F3 were reported 4.12, 4.09 and $4.07 \%$ respectively (Figure 1B). Significant difference in ash content of fresh crackers was not observed due to variation in papaya and whole wheat grain flour ratio. Ash content of crackers gradually decreased with the increasing of storage time (Figure 1B). Highest ash content (3.63\%) was observed in F2 sample, whereas F1 and F3 showed same ash content (3.55\%) at the end of storage period. Moisture absorption may be possible reason behind the decrease in ash content of crackers. However, no significant effect of storage time was reported on the ash content of crackers. This result was in line with the finding of Akubor \& Adejo (2000) who observed similar trend in decreasing of ash content in stored plantain chips.

\subsubsection{Protein content}

Figure 1C showed ratio of papaya and whole wheat flour and it was reported that this combination significantly affected the protein content of fresh crackers. Protein content in crackers increased with the increase of whole wheat flour content. However, maximum protein $(8.14 \%)$ was observed in fresh F3 sample and followed by F2 (7.48\%) and F1 (6.36\%) sample. Data regarding change in protein content of crackers revealed that there was a gradual decrease in protein content throughout the storage period (Figure 1C).

Maximum decrease $(28.75 \%)$ was found in F3 sample while F2 sample had minimum decrease (16.04\%). One of possible reason of decreasing in protein content of crackers during storage is moisture absorption from the atmosphere. Similarly, Akubor \& Adejo (2000) reported a gradual but insignificant decrease in protein content in plantain chips stored in $0.7 \mathrm{~mm}$ thick polyethylene bags $(26.6 \times 18.8 \mathrm{~cm})$. 


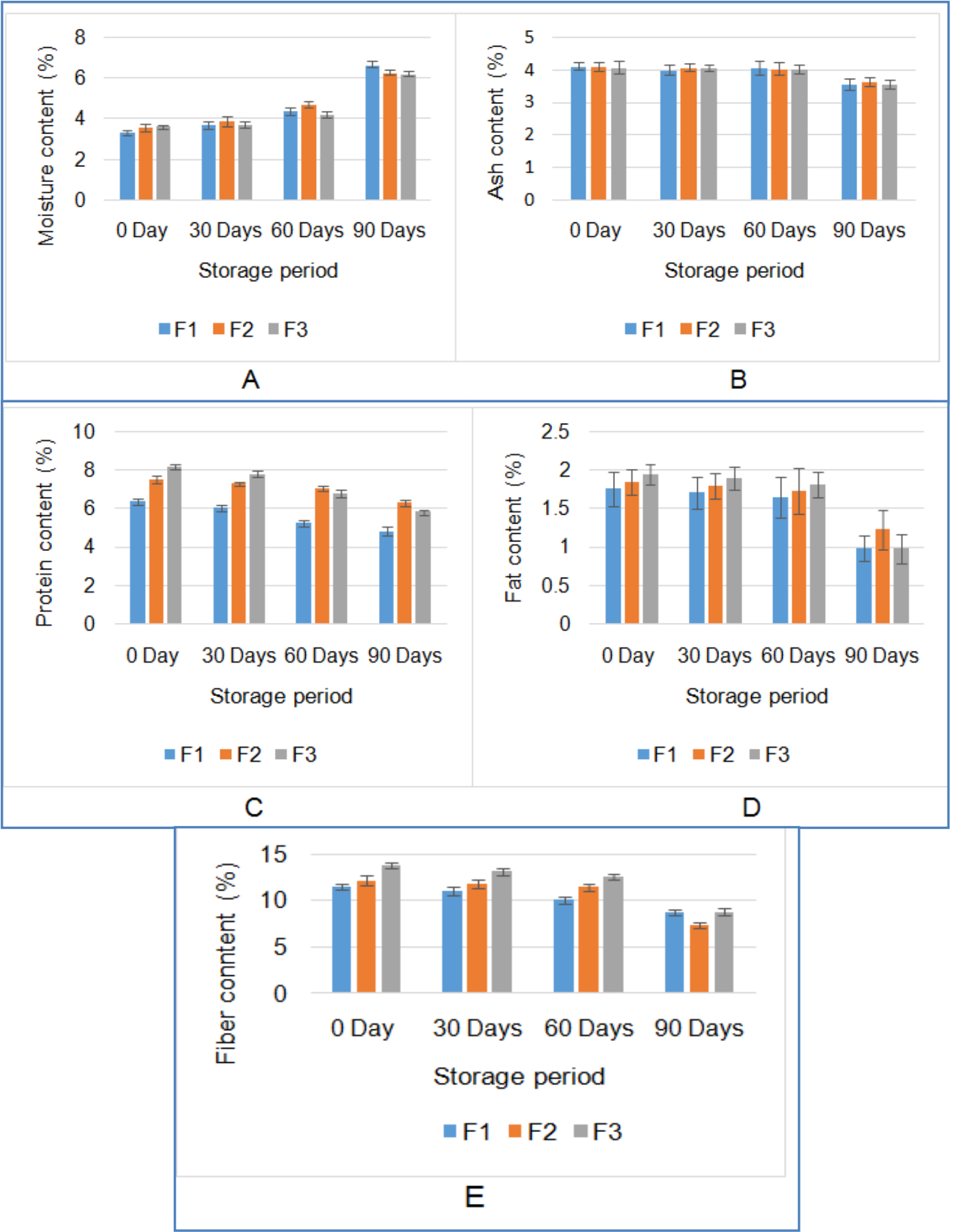

Figure 1 Change in physico-chemical compositions (A-Moisture, B-Ash, C-Protein, D-Fat and E-Fiber content) of crackers during storage period

\subsubsection{Fat content}

Fat content of fresh crackers was significantly affected by ratio of papaya and whole grain flour. Fat content of fresh cracker increased with the decreasing of papaya paste (Figure 1D). Moreover, Figure 1D clearly indicates that fat content decreased with the storage period. During storage period, F3 showed maximum decreasing trend from $1.94 \%$ to $0.98 \%$ and minimum trend $1.84 \%$ to $1.22 \%$ was observed in F2 sample. Decreasing trend in fat content of stored crackers may be resulted due to hydrolysis and oxidation of oil component. These results are in good agreement with Manikantan et al. (2014) who noted increased free fatty acid in stored banana chips. 
in the fiber content was reported with the passage of storage

Fiber content in F1, F2 and F3 combinations of freshly prepared papaya crackers of were $11.5,12.14$ and $13.75 \%$ respectively (Figure 1E). The storage period showed significant effect on fiber content of crackers and a reduction time, whereas maximum decrease (39.54\%) was resulted in F2 sample and minimum $(24.17 \%)$ in F1 sample. Moisture absorption during storage time may be possible reason of decreasing the amount of fiber content in different combinations of papaya crackers.



Figure 2 Change in mineral contents (A-Calcium, B-Magnesium, C-Sodium, D-Potassium and E-Phosphorous) of crackers during storage period 
Association of Official Analytical Chemists (1997) Official

Results of study revealed that incorporation of whole wheat flour had significant effect on mineral contents of papaya crackers (Figure 2). Maximum calcium, magnesium, sodium, potassium and phosphorous value were found in F3 sample and it was $27.24 \%, 123.85 \%, 6.78 \%, 503.72 \%$ and $327.02 \%$ respectively. On the other hand, value of mineral contents decreased in all cracker samples with longer storage period. However, maximum mineral contents were found in F3 sample at 90 days of storage period, whereas minimum minerals in F1 sample (Figure 2). Increasing of moisture might have influenced the mineral contents of crackers during storage period. It is interesting to note that there was no published paper regarding change in mineral content of crackers during storage.

\section{Conclusion}

This study revealed that the ratio of wheat flour and papaya significantly affected the nutrient compositions of crackers. Additionally fiber content was increased and baking process instead of frying resulted in less fat content of the crackers. Storage study also revealed that storage time significantly affected the quality of crackers. Furthermore, it was also reported that high density polyethylene was not sufficient enough to keep the quality of crackers during storage. We also propose to pack crackers in laminated films containing nitrogen flush for long term storage stability. In addition, the effect of storage conditions on oxidative stability of newly formulated crackers could be assessed before the production at industrial scale.

\section{Acknowledgement}

The research work was funded by University Grant Commission through Institute of Research and Training, Hajee Mohammad Danesh Science and Technology University, Dinajpur, Bangladesh.

\section{Conflict of interest}

Authors would hereby like to declare that there is no conflict of interests that could possibly arise.

\section{References}

Akubor PI, Adejo EE (2000) Physicochemical, microbiological and sensory changes in stored plantain chips. Plant Foods for Human Nutrition 55:139-146. DOI: 10.1023/A:1008186224120.

Anuara NS, Zaharia SS, Taiba IA, Rahman MT (2008) Effect of green and ripe Carica papaya epicarp extracts on wound healing and during pregnancy. Food and

Chemical Toxicology 46: 5. DOI: 10.1016/j.fct.2008.03.025. methods of analysis. 16th edition. Washington, D.C. 2.

Ayesha S, Abid N, Anjum FM (2002) Chemical Composition of Three Wheat (Triticumaestivum L.) Varieties as Affected by NPK Doses. International Journal of Agricultureand Biology 4:537-539.

BBS (2011) Year Book of Agricultural Statistics of Bangladesh. Bangladesh Bureau of Statistics. Statistics Division. Ministry of Planning, Government of the Republic of Bangladesh.

Belderok B, Mesdag H, Donner DA (2000) Bread-Making Quality of Wheat - A century of breeding in Europe. Springer Netherlands.

Chowdhury MGF, Islam MN, Islam MS, Islam AFMT, Hossain MS (2008) Study on preparation and shelf-life of mixed juice based on wood apple and papaya. Journal of soil and nature 2:50-60.

Hassan MK (2010) A guide to postharvest handling of fruits and vegetables, Department of Horticulture. Bangladesh Agricultural University Mymensingh, 2202.

Jacobs DR Jr, Marquart L, Slavin J, Kushi LH (1998) Wholegrain intake and cancer: an expanded review and metaanalysis. Nutrition and Cancer 30:85-96.

Jagdeesh SL, Hegde L, Kotimani S, Gorbal K, Reddy BS, Swamy GSK, Basavaraj N, Raghvan GSV (2007) Influence of packaging on storage behavior of jackfruit papad. Journal of Food Science Technology 34:15-19.

Krishna KL, Paridhavi M, Patel JA (2008) Review on nutritional, medicinal and pharmacological properties of papaya (Carica papaya Linn.). Indian Journal of Natural Products and Resources 7:364-373.

Manikantan MR, Shrama R., Kasturi R., Varadharaju N (2014) Storage stability of banana chips in polypropylene based nanocomposite packaging films. Journal of Food Science and Technology 51:2990-3001.DOI 10.1007/s13197-012-0839-0

McKeown NM, Meigs JB, Liu S, Wilson PWF, Jacques PF (2002) Whole-grain intake is favourably associated with metabolic risk factors for type 2 diabetes and cardiovascular disease in the Framingham Offspring Study. American Journal of Clinical Nutrition 76:390-398.

Mondal MF, Rahman MA, Pramanik MAJ (1995) Effects of different post harvest treatments on physio-chemical changes and shelf life of mango. Bangladesh horticulture 23:1-5.

Purohit C, Rajyalakshmi P (2011) Quality of products containing defatted groundnut cake flour. Journal of Food Science and Technology 48:26-35.doi: 10.1007/s13197-0100125-y. 
Rovira DD (2009) Technology and Engineering. Accessed online on 23rd March, 2010 from http://books.google.ca/ books?isbn $=0813821355$.

Sudha ML, Vetrimani R, Leelavathi K (2007) Influence of fibre from different cereals on the rheological characteristics of wheat flour dough and on biscuit quality. Food Chemistry 100:1365-1370.doi:10.1016/j.foodchem.2005.12.013.

Thunstrom JN (2011) Economic policies for healthier food intake: the impact on different household categories. The
European Journal of Health Economics 12:127-140.doi: 10.1007/s10198-010-0234-6.

Tietze HW (2002) Health and Fitness. Harald W. Tietze Publishing Property Limited, Bermagui.

Vergara-Valencia N, Granados-Pérez E, Agama-Acevedo E, Tovar J, Ruales J, Bello-Pérez LA (2006). Fibre concentrate from mango fruit: Characterization, associated antioxidant capacity and application as a bakery product ingredient. Lebensmittel-Wissenchaft und-Technologie 40:722729.doi:10.1016/j.lwt.2006.02.028 